\title{
Positive Equality Duties: The Future of Equality and Transparency?
}

\author{
Alysia Blackham (D), Associate Professor and Discovery Early Career Researcher at Melbourne Law School
}

University of Melbourne, Victoria, Australia

\begin{abstract}
Transparency is a radical expectation in the context of equality law. In a system highly dependent on individual enforcement, the lack of transparency in individual claiming dramatically limits the potential of equality law to achieve systemic change. Overcoming discrimination that is systemic, embedded, and pervasive requires moving beyond confidential mechanisms for addressing discrimination. Given that the implementation of workplace equality law occurs in practice at the organisational level, there is a growing need to focus on what employers are actually doing to achieve equality, and how their practices are accountable to those affected and the broader community. In this article, drawing on case studies from the United Kingdom and Australia, I consider how corporate and governmental transparency might be extended to equality and discrimination, by embedding such obligations within positive equality duties. I consider how the publication of equality information under the Public Sector Equality Duty in the UK, and more limited gender pay gap reporting in the UK and Australia, have promoted transparency and addressed inequality. Considering theories of targeted transparency and action cycles, I put forward five key criteria to make transparency via positive equality duties effective. I consider the limitations of existing models, and put forward suggestions for how transparency might be better embedded and enacted in future positive equality duties.
\end{abstract}

Keywords - equality, transparency, positive duties, mainstreaming

Acknowledgments: This research was funded by the Australian Government through the Australian Research Council's Discovery Projects funding scheme (Project DE170100228). The views expressed herein are those of the author and are not necessarily those of the Australian Government or Australian Research Council.

Disclosure statement: No potential conflict of interest was reported by the authors.

License: This work is under Attribution-NonCommercial-ShareAlike 4.0 International (CC BY-NC-SA 4.0)

https://creativecommons.org/licenses/by-nc-sa/4.0/

Suggested citation: Blackham, A. (2021). "Positive Equality Duties: The Future of Equality and Transparency." Law in Context, 37 (2): 98-118, DOI: https://doi.org/10.26826/law-in-context.v37i2.150

\section{Summary}

1. Introduction

2. Positive Equality Duties

3. Designing Effective Positive Duties

4. Positive Equality Duties and Transparency in Practice 4.1 United Kingdom

4.2 Australia 4.2.1 Victoria
4.2.2 Tasmania

4.2.3 Australian Capital Territory

4.3 Gender Pay Gap Reporting

4.3.1 United Kingdom

4.3.2 Australia

5. Discussion and Conclusion

6. References 


\section{INTRODUCTION}

Transparency is a radical expectation in the context of equality law. To date, most enforcement of equality law has occurred behind closed doors. Individual claims are most often settled via confidential conciliation (Blackham and Allen 2019), with parties often bound by strict nondisclosure agreements. Statutory secrecy obligations in legislation and budget cuts mean that equality agencies rarely reveal much about the claims that they receive or how they are resolved (Allen and Blackham 2019). In a system highly dependent on individual enforcement, the lack of transparency in individual claiming dramatically limits the potential of equality law to achieve systemic change. Secrecy can protect wrongdoers from accountability for their actions, inhibit organisational change, and prevent better processes and actions from being taken in the future. Overcoming discrimination that is systemic, embedded, and pervasive (Sturm 2001) requires moving beyond confidential mechanisms for addressing discrimination.

Given that the implementation of workplace equality law occurs in practice at the organisational level, there is a growing need to focus on what employers are actually doing to achieve equality, and how their practices are accountable to those affected and the broader community. Organisations are already required to collect and report on data on various issues. This includes environmental impact, supply chains, board diversity, executive remuneration, tax and revenue, and workplace health and safety. This information is reported to various stakeholders, including shareholders, employees and external regulators. Corporate transparency, it is said, facilitates corporate accountability. Owen (2003, p. 2) says:

The whole raison d'etre for social and environmental accounting lies in its potential to make certain aspects of corporate activitore transparent to external stakeholders, who may then be empowered to hold corporate management accountable for their actions insofar as they are affected by them.
Drawing on case studies from the United Kingdom (UK) and Australia, I consider how corporate and governmental transparency might be extended to equality and discrimination, by embedding such obligations within positive equality duties. I consider how the publication of equality information under the Public Sector Equality Duty in the UK, and more limited gender pay gap reporting in the UK and Australia, have promoted transparency and addressed inequality. I consider the limitations of existing models, and put forward suggestions for how transparency might be better embedded in future positive equality duties.

\section{POSITIVE EQUALITY DUTIES}

Positive equality duties are seen as a "fourth generation" of equality law (Fredman 2011, pp. 299-302; see further 2008, chap. 7), having the potential to reframe the entire structure and orientation of discrimination law. Positive equality duties seek to encourage more proactive and preventative approaches to achieving equality (Dickens 2006, p. 447; 2007, p. 474; Fredman 2012, p. 271), shifting the onus from individuals to organisations to detect and address unlawful discrimination (Fredman 2012, p. 266). Positive duties represent a "radical strategy for tackling deep-seated discrimination" (Davies 2009, p. 135) that could revolutionise "the whole landscape of discrimination law" (Fredman 2012, p. 271). Duties seek to prompt organisations to proactively scrutinise and reform their own operations, without external intervention (Hepple 2011, p. 326). They can also help promote the mainstreaming of equality, integrating equality into organisational decision-making and processes (McCrudden 1998-1999, p. 1699).

While positive equality duties have a number of ambitious aims, transparency is a key tool in prompting proactive organisational approaches to equality (Government Equalities Office 2010). As noted by the report of the UK House of Commons Women and Equalities Committee following its inquiry into Older People and Employment: 
Transparency can drive progress, and facilitate accountability for change ... if employers were required to disclose data concerning the age make-up of their employees it would show where the issues lie, as an important starting point in achieving that cultural change (Women and Equalities Committee 2018a, p. 16).

The collection and analysis of data is a key way in which organisations can scrutinise their own operations; it is therefore fundamental for organisations to effectively self-regulate their own equality outcomes (Manfredi, Vickers, and Clayton-Hathway 2018, p. 393).

Transparency can be achieved through duties that compel or encourage employers to reveal certain information, such as pay or workforce composition data. This reflects a form of targeted transparency (as opposed to broad, governmental transparency). According to Fung and others:

Targeted transparency aims to reduce specific risks or performance problems through selective disclosure by corporations and other organizations. The ingeniousness of targeted transparency lies in its mobilization of individual choice, market forces, and participatory democracy through relatively light-handed government action (Fung, Graham, and Weil 2007, 5).

Here, the risk or performance problem is inequality or discrimination in how organisations operate, including in their employment practices and performance of their functions. According to Fung and others, targeted transparency is particularly warranted where information asymmetries risk perpetuating discrimination or social inequalities (Fung, Graham, and Weil 2007, pp. 40-41).

Incorporating transparency into employer processes can substantially improve the quality of the processes themselves. For example, in their empirical study of equal pay audits in the UK, Deakin and others found that transparency was fundamental for securing the ef- fectiveness of equal pay audits (Deakin, McLaughlin, and Chai 2011, p. 123). Where audits were conducted in secret, they tended to be narrow in scope, and had less awareness of drivers of gender inequality. By contrast, transparent pay audits "led to a deeper analysis of the causes of the pay gap and related gender issues" (Deakin, McLaughlin, and Chai 2011, p. 123). Further, the results of transparent processes can be "assessed and challenged", and can lead to meaningful engagement and deliberation by and with stakeholders (Deakin, McLaughlin, and Chai 2011, p. 123).

By compelling organisations to release certain data, positive duties require organisations to both collect and analyse relevant data. Without such duties, organisations can be reluctant to prioritise data collection and reporting: for some, being ignorant of a problem absolves the organisation of responsibility for addressing it. ${ }^{1}$ For others, particularly in times of crisis and austerity, data collection and reporting is not seen as an organisational priority, at least without regulatory prompting. Without an obligation to gather and analyse data, employers may be unaware there is even a problem within an organisation (Government Equalities Office 2015, p. 13).

The limited take-up of voluntary reporting is well illustrated by the experience of the UK in relation to workforce age composition reporting. In February 2017, a UK-based initiative commenced asking employers to commit to increasing the number of people in their workforce aged 50 to 69 , and to report on the age composition of their workforce (Women and Equalities Committee 2018a, p. 16). Employers were asked to report by the end of 2017. By the time the Women and Equalities Committee prepared its inquiry report in June 2018, a grand total of 10 employers had published their workforce data (Women and Equalities Committee 2018a, p. 16). When I attempted to locate these publications in July 2020, the website had been removed (perhaps implying that reporting had not increased overly in subsequent years).

\footnotetext{
${ }^{1}$ In relation to gender pay gap reporting, $2 \%$ of UK respondents who did not conduct gender pay gap reviews cited fear of what they would find as a reason for not conducting the review (Winterbotham et al. n.d., 24).
} 
The UK had a similar experience of voluntary gender pay gap reporting. There has traditionally been a reluctance in the UK to impose mandatory gender pay gap reporting on UK employers. In the 2000s, there was instead a focus on encouraging voluntary equal pay audits within organisations, by focusing on the business case for equality, promoting tool kits and resources, and rewarding good practice (Deakin, McLaughlin, and Chai 2011, p. 117). This voluntary approach had limited impact in practice: a telephone survey conducted in September 2014 with 855 private and voluntary sector UK employers who employed 150 or more staff found that $31 \%$ of respondents had conducted or were conducting a formal gender pay gap review (Winterbotham et al. n.d., p. 22), and $41 \%$ currently analysed pay data to explore the gender pay gap (Winterbotham et al. n.d., 20). Of those who had not conducted a formal pay gap review, the vast majority (89\%) said this was because they already provided equal pay (Winterbotham et al. n.d., p. 24). How this could be known without a pay gap review or data analysis is entirely unclear.

Of employers who had conducted a pay review, only $13 \%$ had reported this data: $10 \%$ had reported this data internally, and $7 \%$ had reported externally (Winterbotham et al. n.d., p. 29). Overall, only 4\% of all surveyed employers had voluntarily reported on their gender pay gap, either internally or externally (Winterbotham et al. n.d., p. 29); this was despite 63\% of respondents saying that ensuring there was no gap between men's and women's pay was a high or fairly high priority for their organisation (Winterbotham et al. n.d., p. 14). Two-thirds of respondents (66\%) had adopted or planned no approach at all for reducing their organisations' gender pay gap (Winterbotham et al. n.d., 14). Thus, voluntary measures appeared largely ineffectual across the vast majority of UK employers.

While UK employers might be uniquely reticent in this area, it is more likely that promoting transparency cannot be a voluntary initiative: employers do not have the will or the inclination to be proactive in this space without regulatory intervention. In the 2014 survey of UK employers in relation to gender pay gap reporting, for example, respondents cited an employee complain- ing or taking legal action (37\%) and complying with legislation (13\%) as key factors that might prompt them to examine their gender pay gap (30\% said this question was not relevant to them, as they already had equal pay) (Winterbotham et al. n.d., p. 26).

Requiring data to be collected, analysed and released focuses organisational attention on equality and discrimination within an organisation. Andy Briggs, the CEO of Aviva UK Insurance, as the UK Government Business Champion for Older Workers, therefore gave evidence to the Women and Equalities Committee that "ultimately, my experience of working in business is that if things are measured and published, it does get greater focus within a business" (Women and Equalities Committee 2018a, p. 17). Fear of releasing data that casts organisations in a negative light, and subsequent reputational impacts ('shaming'), can also be an important prompt for change (see Blackburn and Hart 2003, pp. 63-64; Wooten and James 2004; James and Wooten 2006; Barnes and Burke 2012, pp. 171-72, p. 189). The UK Women and Equalities Committee therefore recommended that, to address age discrimination at work, "the Government introduce mandatory regulations to require all public-sector employers, and private and voluntary sector employers with more than 250 staff, to publish the age profile of their workforce" (Women and Equalities Committee 2018a, p. 17). The UK government, however, would not accept this recommendation without further evidence of the need for such transparency:

The Government sees the value in companies being transparent about the age make up of their workforce. The Civil Service already does this, as do many leading employers. ... In terms of introducing mandatory regulation, Government would need more evidence about the efficiency and impact of such a measure to see whether it could justify placing an additional burden on employers. By way of comparison, the introduction of mandatory gender pay gap reporting was estimated to have a net annual cost to business of $£ 3.8 \mathrm{~m}$ (at 2014 prices) (Women and Equalities Committee 2018b, p. 4). 
Thus, while increased transparency has great potential to focus and direct organisational attention to addressing inequality, it is not always seen as economically or politically beneficial given the costs involved (Fung, Graham, and Weil 2007, p. 43).

\section{DESIGNING EFFECTIVE POSITIVE DUTIES}

While transparency through positive duties has great potential to promote equality, the release of information in and of itself is not enough. Positive duties need to be designed in a way that maximises the impact of transparency in achieving equality. Fung and others argue that targeted transparency policies have five key characteristics, which I have adapted for our purposes:

1. Mandated public disclosure

2. By private or public organisations

3. Of standardized, comparable, and disaggregated information

4. Regarding specific (equality) practices

5. To further a defined public purpose (here: the pursuit of equality) (Fung, Graham, and Weil 2007, 6).

Fung and others argue that enacting a general policy into specific transparency requirements entails a further five features:

1. A specific policy purpose (such as addressing inequality)

2. Specified information disclosers (and possibly users)

3. A defined scope of information to be disclosed

4. A defined information structure and vehicle (that is, information metrics, how information should be disclosed, how often, and in what format)

5. An enforcement mechanism (Fung, Graham, and Weil 2007, p. 39).

Where transparency policies achieve their aims, they do so through an "action cycle", which Fung and others see as having five steps (again, which I have adapted):

1. Information users perceive and understand disclosed information

2. And therefore choose more equality-advancing options.
3. Information disclosers perceive and understand users' changed choices

4. And therefore improve their practices

5. That in turn reduce the risks of inequality (Fung, Graham, and Weil 2007, p. 6).

This is depicted in FIGURE 1.

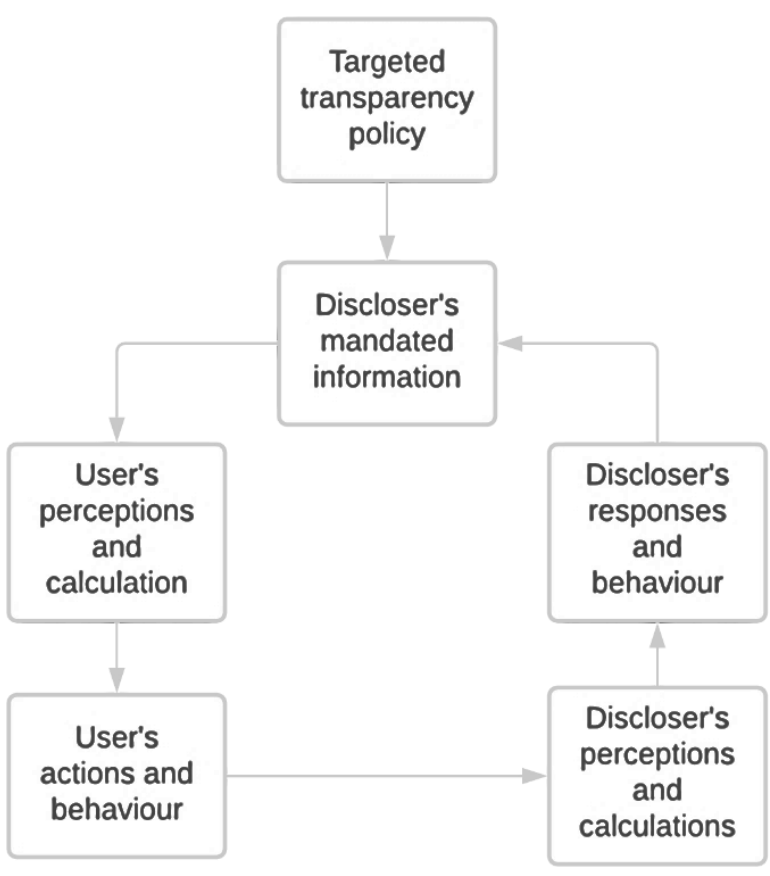

FIGURE 1: Targeted Transparency Action Cycle

This action cycle is not only grounded in consumption but also in broader engagement by information users, who can include consumers, investors, and employees (Fung, Graham, and Weil 2007, p. 48). Thus, these policies exert market-based, organisational and political pressure for change (Fung, Graham, and Weil 2007, p. 49). One challenge in applying this model to the public service in particular, however, is that people tend to have limited choice when engaging with government; there is only one government agency that provides social security payments, for example. Fundamental issues for the action cycle in the context of positive equality duties, then, are (1) whether equality information will be sufficiently influential on user decision-making to change user behaviour; and (2) whether users will have sufficient 'choice' in this context to influence 
organisational decision-making (see, eg, Fung, Graham, and Weil 2007, p. 174).

A range of established actors could be seen as key information users in the equality context. For listed companies, shareholders can play a key role in addressing discrimination and promoting equality. The presence of shareholders may increase organisational visibility and the importance of reputation, providing an incentive for companies to adopt best practice in equality matters (Felstead et al. 2002, p. 57; Wood, de Menezes, and Lasaosa 2003, pp. 223). Deakin and others (2012, pp. 131-32) found that workplaces listed on the stock market were more likely to have formal equal opportunity policies that mentioned gender, though they were no more likely to actually monitor or review their activities for potential discrimination.

Trade unions and collective employee bodies can also play a key role in this area. The presence of trade unions may increase external scrutiny of an organisation and its equality practices (Felstead et al. 2002, p. 57). Unionised workplaces are more likely to have formal equal opportunity policies (Hoque and Noon 2004, p. 488; Kersley et al. 2006, p. 239), monitoring and review activities (Kersley et al. 2006, p. 248), and a "strategic approach" to equality issues (Barnes, Smeaton, and Taylor 2009, p.p. 35, 80). However, the decline in union membership and the coverage of collective activity makes this form of scrutiny increasingly problematic.

While Fung and others' model might need adapting before being applied to equality transparency policies, it draws our attention to five key criteria to make transparency via positive equality duties effective.

First, there is a need for information quality. Quality in this context has a number of elements. To be effective, transparency must be based on "detailed and material information" (Landau and Marshall 2018, p. 329) which is "broadly comparable in quality, detail and vocabulary" (Landau and Marshall 2018, p. 330) to facilitate benchmarking across and between organisations and industries. More generally, organisations need to report the right information: that is, data on measures that are meaningful and relevant to promoting equality. In relation to equality law, for example, data rarely consider intersectional experiences (Women and Equalities Committee 2018a, p. 15; Manfredi, Vickers, and ClaytonHathway 2018, p. 394), even though these are key to understanding how people actually experience discrimination in practice (Blackham and Temple 2020). Data also need to be accurate, and collected using systems that are robust and have integrity. In relation to equality information, employees, potential employees and service users may be reluctant to reveal sensitive personal information; this is likely to limit the comprehensiveness and accuracy of the data held by organisations (Manfredi, Vickers, and Clayton-Hathway 2018, p. 394). Manfredi and others therefore argue that there is a need to build trust among such individuals, to ensure the data that are gathered are a reliable and accurate basis on which to evaluate and review policies and procedures (Manfredi, Vickers, and Clayton-Hathway 2018, p. 394).

Second, and relatedly, information needs to be readily accessible and made available to information users; disclosure then helps to address the information asymmetry between organisations and those to whom they are accountable (Landau and Marshall 2018, p. 329; Fung, Graham, and Weil 2007, p. 40). It is only when information is easily accessible that it can enter into users' calculus and inform their actions (Fung, Graham, and Weil 2007, 54): "the cost of acquiring and using new information must be low enough to justify users' efforts in relation to expected benefits" (Fung, Graham, and Weil 2007 , p. 56). Accessibility in this context means that information should not be buried on a website or in an appendix to an annual report. Rather, information needs to be distributed directly to relevant stakeholders, in a format that makes data accessible, comprehensible and meaningful. Further, there is a need for the centralised aggregation, analysis and reporting of data across organisations and industries, to facilitate effective benchmarking and public scrutiny of information. Thus, as Fung and others argue, transparency needs to be 'usercentred' (Fung, Graham, and Weil 2007, p. 11).

Third, information users should be consulted and engaged with in the process of gathering, evaluating, and responding to organisational data. Revealing information alone is not enough: disclosure must be part of 
an 'action cycle' in which stakeholders are engaged in analysing, critiquing, and feeding back information to the organisation. This embeds user responses into organisational decision-making (Fung, Graham, and Weil 2007 , p. 11), with the ultimate aim of achieving organisational change (Landau and Marshall 2018, p. 329). Thus, disclosure is part of an active process of engagement with community actors and stakeholders. Importantly, too, this process of engagement must reach the right participants, with conscious efforts made to not exclude more marginal voices (Manfredi, Vickers, and Clayton-Hathway 2018, pp. 394-95). As Manfredi and others argue, consultation must have both reach and depth, be participatory, and focus on deliberation and openness (Manfredi, Vickers, and Clayton-Hathway 2018, p. 398).

Fourth, there need to be accessible, efficient and effective procedures in place to monitor, scrutinise and enforce positive duties if they have not been complied with. How best to enforce a positive duty is one of the more contentious issues in contemporary equality law, especially given individuals rarely enforce their own individual rights to be protected from discrimination (See, eg, Blackham 2020). Positive duties - including duties aimed at increasing transparency - are aimed at achieving systemic and cultural change, including through the mainstreaming of equality. Ideally, this might mean there is no need for enforcement: if information is embedded and mainstreamed in organisational decisionmaking, addressing inequality will become part of how an organisation operates, without external prompting. More realistically, enforcement will be required to ensure targeted transparency is effective (Fung, Graham, and Weil 2007, p. 45).

The question for positive duties is: who should be tasked with their enforcement? As positive duties are largely aimed at structural change, individuals may not have a sufficient interest in such matters to take the lead on enforcement. Equally, it is not always possible for statutory equality agencies, with limited budgets and staffing, to monitor the behaviour of every organisation which is subject to a duty. That said, Fung and others see "[m]onitoring nonreporting or misreporting and then levying penalties for those who violate disclosure requirements" as essential to the success of these regimes (Fung, Graham, and Weil 2007, pp. 45, 179). To some extent, and in some contexts, a requirement to consult or engage with key stakeholders may operate as an enforcement mechanism, especially where organisations are engaging with established collective actors like unions. Further, the process of collecting and analysing data might operate to prompt a form of internal self-regulation by organisations themselves (Manfredi, Vickers, and Clayton-Hathway 2018, p. 371). Even in this context, there needs to be a mechanism for resolving disputes that cannot be solved at the local level, or addressing cases where organisations simply fail to engage or engage fully with the process of transparency. Finding an effective balance between individual, collective, agency and organisational self-enforcement is a key challenge for positive duties.

Fifth, Fung and others argue that transparency policies need to be sustainable, and grow in use and scope over time (Fung, Graham, and Weil 2007, p. 11). Transparency policies are the result of political compromises, that limit their initial scope and impact (Fung, Graham, and Weil 2007, p. 11). Policies need to be continuously refined and improved to rectify identified gaps in information and compliance. Thus, there is a need for the ongoing evaluation and refinement of positive duties (Fung, Graham, and Weil 2007, p. 179).

It is clear, then, that building transparency, data collection and reporting into positive equality duties is potentially a key mechanism for achieving organisational change. However, the devil is in the detail: requiring data to be reported is not sufficient to achieve meaningful change. We must be attuned to the extent to which positive duties achieve data quality, data accessibility and meaningful engagement in practice. It is to these questions to which I turn in the next section. 


\section{POSITIVE EQUALITY DUTIES AND TRANSPAR- ENCY IN PRACTICE}

\subsection{UNITED KINGDOM}

The Great Britain (GB) Public Sector Equality Duty (PSED) requires public authorities or people exercising public functions to, in exercise of their functions, have "due regard" to the need to:

- eliminate discrimination, harassment, victimisation and conduct prohibited by the Equality Act 2010 (UK);

- $\quad$ advance equality of opportunity between persons who share and do not share a protected characteristic; and

- foster good relations between persons who share and do not share a relevant protected characteristic. $^{2}$

The general PSED is complemented by specific duties, which are designed to facilitate compliance with the general duty. These specific duties differ across England, Wales, and Scotland.

The GB PSED was based on the statutory duty in Northern Ireland under the Northern Ireland Act $1998 \mathrm{~s}$ $75(1)$, which requires a public authority to:

[I]n carrying out its functions relating to Northern Ireland have due regard to the need to promote equality of opportunity-

(a) between persons of different religious belief, political opinion, racial group, age, marital status or sexual orientation;

(b) between men and women generally;

(c) between persons with a disability and persons without;

and

(d) between persons with dependants and persons without.
The publication of information is seen as a fundamental feature of positive duties in the UK. Grosser and Moon (2008, p. 181) write that "it is implicit in the Public Sector Duty that increased transparency afforded by monitoring and reporting would improve gender equality". A 2012 Equality and Human Rights Commission (EHRC) report on the publishing of equality information noted a number of benefits of making equality information accessible, including that it encouraged public authorities to: identify equality challenges; find ways to mitigate adverse impacts on particular groups; come to understand how policies and practices impact on different groups; set equality objectives based on robust evidence; and have baseline data to evaluate the impact of different initiatives (EHRC 2012, p. 4).

Under the Equality Act 2010 (Specific Duties) Regulations 2011 (UK) SI 2011/2260, public authorities must publish information to demonstrate their compliance with the PSED, 3 including by publishing information relating to employees who share a relevant protected characteristic (but only where the public authority has 150 employees or more). ${ }^{4}$ However, the EHRC found in 2012 that only $50 \%$ of public authorities had published sufficient equality information on their staff and services to meet their obligations under the duty; and only $78 \%$ had taken some steps to publish equality information (EHRC 2012, pp. 5-6, 8). Thus, the EHRC report raises concerns about the effectiveness of the PSED, and the specific duties in particular, in ensuring the publication and reporting of information.

In Wales, the Equality Act 2010 (Statutory Duties) (Wales) Regulations 2011 (Wales) SI 1064/2011 (W155) includes specific duties relating to the collection and publication of information. Public authorities must make such arrangements as they consider appropriate to identify, collect, and publish information that relates to compliance with the PSED, 5 and collect and publish information about the protected characteristics of all

\footnotetext{
${ }^{2}$ Equality Act 2010 (UK) s 149.

${ }^{3}$ Equality Act 2010 (Specific Duties) Regulations 2011 (UK) SI 2011/2260, reg 2(1).

${ }^{4}$ Ibid reg 2(4)-(5).

${ }^{5}$ Equality Act 2010 (Statutory Duties) (Wales) Regulations 2011 (Wales) SI 1064/2011 (W155) reg 7.
} 
their employees. ${ }^{6}$ Public authorities must "take all reasonable steps" to ensure that information which they are required to publish is accessible by persons who share one or more protected characteristics. ${ }^{7}$ Going further than in England, Welsh public authorities must also make such arrangements as they consider appropriate to assess the likely impact of policies on compliance with the PSED, monitor the impact of policies on compliance with the PSED, and publish reports on their assessments. ${ }^{8}$ Further, Welsh authorities and Ministers must report on progress towards complying with the general duty. ${ }^{9}$

The specific duties in Scotland also have a particular focus on reporting. Under the Equality Act 2010 (Specific Duties) (Scotland) Regulations 2012 (Scot) SI 2012/162,10 public authorities in Scotland must report on "mainstreaming", by publishing reports every two years on the progress made to make the PSED "integral to the exercise of its functions so as to better perform that duty". ${ }^{11}$ Scottish authorities must also publish equality outcomes, and report on progress to achieve those outcomes every two years; 12 and are required to assess the impact of proposed or revised policies, considering evidence relating to persons who share a protected characteristic, and publish the results. ${ }^{13}$ Authorities must also gather and publish information on the composition of their workforce, and recruitment, retention and development of employees, with respect to protected characteristics. ${ }^{14}$ This information must be used to "better perform the equality duty". ${ }^{15}$ The Scottish Ministers must also take steps to gather information on the protected characteristics of members of public authorities, and to provide that information to the listed authority. ${ }^{16}$ The listed authority must then use the information to better perform the equality duty. ${ }^{17}$

Gender pay gap information must be published for authorities with 20 or more employees, ${ }^{18}$ as must an equal pay statement relating to occupational segregation and pay differentials based on gender, race and disability. ${ }^{19}$ Published information must be accessible to the public. ${ }^{20}$ Again, these specific duties are far more comprehensive than those in England. They also have a far stronger focus on reporting on mainstreaming, which is absent in England.

It appears that the more detailed reporting requirements in Scotland are prompting fairly high compliance with the specific duties. In a 2015 survey of public authority compliance with the specific duties, the EHRC in Scotland found that $96 \%$ of public authorities published a mainstreaming report and reported on progress made to achieve their equality outcomes; $95 \%$ published gender pay gap information; and $89 \%$ published some employee information (though this varied across the

\footnotetext{
${ }^{6}$ Ibid reg 9.

${ }^{7}$ Ibid reg 6.

${ }^{8}$ Ibid reg 8 .

${ }^{9}$ Ibid reg 16, 17 .

10 The 2012 Regulations were amended in 2015 to expand the listed authorities: The Equality Act 2010 (Specific Duties) (Scotland) Amendment Regulations 2015 (Scot) SI 2015/254; and in 2016: The Equality Act 2010 (Specific Duties) (Scotland) Amendment Regulations 2016 (Scot) SI 2016/159.

${ }^{11}$ Equality Act 2010 (Specific Duties) (Scotland) Regulations 2012 (Scot) SI 2012/162 reg 3. This reflects a broader Scottish commitment to mainstreaming (Scottish Government 2015). See Breitenbach (2004) in relation to gender.

12 Equality Act 2010 (Specific Duties) (Scotland) Regulations 2012 (Scot) SI 2012/162 reg 4.

13 Ibid reg 5.

${ }^{14}$ Ibid reg 6.

${ }^{15}$ Ibid reg 6(2).

${ }^{16}$ Ibid reg 6A; as amended by The Equality Act 2010 (Specific Duties) (Scotland) Amendment Regulations 2016 (Scot) SI $2016 / 159$ reg 4.

${ }^{17}$ Ibid.

${ }^{18}$ Ibid reg 7; as amended by The Equality Act 2010 (Specific Duties) (Scotland) Amendment Regulations 2016 (Scot) SI 2016/159 reg 5 , 6 (previously 150 employees).

${ }^{19}$ Ibid reg 8.

${ }^{20}$ Ibid reg 10.
} 
protected characteristics) (Equality and Human Rights Commission Scotland 2015a). Thus, compliance was fairly high across the Scottish authorities, though there was scope to improve the quality of information published (Equality and Human Rights Commission Scotland 2015b).

In a follow up survey conducted in 2017, 93\% of public authorities had published a mainstreaming report, and 94\% had published equality outcomes (EHRC 2017). Only $90 \%$ reported on progress made to achieve their equality outcomes, down from 96\% in 2015. Further, only $57 \%$ reported using evidence in developing their outcomes, and 52\% reported involving people who share a relevant protected characteristic in development outcomes. It is possible, though, that some authorities gathered evidence and involved communities without explicitly reporting it. Overall, compliance remains fairly high across the Scottish public authorities.

Similar, though less detailed, reporting obligations are imposed on authorities in Northern Ireland (NI) who must consult on ${ }^{21}$ and submit a scheme to the Equality Commission of Northern Ireland (ECNI) showing how they propose to fulfil their obligations under the equality duty, ${ }^{22}$ including in relation to assessing compliance, consulting, monitoring any adverse impact of policies and publishing the results, and ensuring public access to information and services. ${ }^{23}$
In terms of developing an action cycle to advance transparency, the English PSED does not include any duty to consult on equality matters. ${ }^{24}$ In Wales, however, the Equality Act 2010 (Statutory Duties) (Wales) Regulations 2011 (Wales) SI 1064/2011 (W155) include specific duties relating to consultation and involvement. Public authorities must comply with engagement provisions in developing equality objectives, ${ }^{25}$ identifying relevant information for publication, ${ }^{26}$ carrying out an assessment, ${ }^{27}$ and making or revising a Strategic Equality Plan. ${ }^{28}$ These engagement provisions require the involvement of persons who share one or more of the protected characteristics, and who have an interest in the way that the authority carries out its functions; and involving and consulting other persons as the authority considers appropriate, in carrying out an activity. ${ }^{29}$ Consultation is at the heart of the Welsh approach to governance, ${ }^{30}$ and the specific duties extend that to equality issues (Foster 2015, p. 156). Consultation is also built into the enforcement of the NI duty, where authorities must consult on ${ }^{31}$ the scheme for fulfilling their obligations under the equality duty, ${ }^{32}$ and include information in that scheme on how they will consult on equality matters. ${ }^{33}$ Thus, the devolved nations offer some insights into how consultation and engagement could be integrated into the specific duties, including to promote a transparency action cycle.

\footnotetext{
${ }^{21}$ Northern Ireland Act 1998 sch 9, s 5.

${ }^{22}$ Ibid sch 9, s 2(1), 4(1).

${ }^{23}$ Ibid sch 9, s 4(2).

${ }^{24}$ This may be compared with the previous duties for race, gender and disability equality, which all included some engagement component.

${ }^{25}$ Equality Act 2010 (Statutory Duties) (Wales) Regulations 2011 (Wales) SI 1064/2011 (W155) reg 4.

${ }^{26}$ Ibid reg 7.

${ }^{27}$ Ibid reg 8.

${ }^{28}$ Ibid reg 15.

${ }^{29}$ Ibid reg 5.

${ }^{30}$ These provisions are like those that were in the original draft of the English regulations (Hepple 2011, pp. 326-27).

${ }^{31}$ Northern Ireland Act 1998 sch 9, s 5.

${ }^{32}$ Ibid sch 9, s 2(1), 4(1).

${ }^{33}$ Ibid sch 9, s 4(2).
} 
In relation to enforcement, the PSED can be enforced by both the EHRC and judicial review in the civil courts (not Employment Tribunals); it creates no cause of action at private law. ${ }^{34}$ The PSED is designed so that these enforcement mechanisms should generally not need to be exercised: as Manfredi and others have argued, 'the PSED is designed as second-generation regulation, which aims to achieve a culture of compliance, rather than relying on coercive court proceedings' (Manfredi, Vickers, and Clayton-Hathway 2018, p. 370). The PSED is grounded in "responsive proceduralized self-regulation, in which compliance is based on developing the capacity of institutions to address inequality" (Manfredi, Vickers, and Clayton-Hathway 2018, p. 371). By changing organisational systems and processes, and restructuring organisational decision-making, it is hoped that organisations will achieve equality aims by changing their internal operations (Manfredi, Vickers, and Clayton-Hathway 2018, p. 371), consistent with reflexive law (Blackham 2019). Critics of the PSED have argued that its focus on procedure has led to a "box ticking" mentality and an excessive focus on proceduralism, which has been exacerbated by judicial review's focus on process not outcome (Manfredi, Vickers, and Clayton-Hathway 2018, pp. 374-75; Fredman 2012, pp. 275-76).

In 2013, a review was conducted of the PSED. Manfredi and others examined the evidence presented to that review, to evaluate how the duty was operating in practice (Manfredi, Vickers, and Clayton-Hathway 2018). They found that public authorities who participated in the review often reported that they had improved their data collection and monitoring systems in response to the PSED (Manfredi, Vickers, and ClaytonHathway 2018, p. 381). This helped to identify disadvantaged groups, and often led to a review of services to achieve more equitable outcomes (Manfredi, Vickers, and Clayton-Hathway 2018, p. 381). Manfredi and

\footnotetext{
${ }^{34}$ Equality Act 2010 (UK) s 156.

${ }^{35}$ Equal Opportunity Act 2010 (Vic) s 15(2).

36 Ibid s 15(6).

${ }^{37}$ Ibid s 15(3).

38 Ibid s 15(4).
}

others also identified a number of examples of good practice in relation to consultation, and found that this participative dimension helped to empower non-government organisations to hold government authorities to account (Manfredi, Vickers, and Clayton-Hathway 2018, pp. 379-81).

\subsection{AUSTRALIA}

Positive duties are less widespread in Australian equality law, and do not typically focus on transparency or reporting. However, positive duties are in place in some Australian states and territories.

\subsubsection{VICTORIA}

In Victoria, those who have a duty not to discriminate under the Equal Opportunity Act 2010 (Vic) (including employers), "must take reasonable and proportionate measures to eliminate that discrimination, sexual harassment or victimisation as far as possible". ${ }^{35}$ What is "reasonable and proportionate" depends on:

- the size of the business;

- the nature and circumstances of the business;

- available resources;

- business and operational priorities; and

- practicability and the cost of the measures. ${ }^{36}$

This duty is not subject to individual enforcement; 37 rather, it may be the subject of an investigation by the Victorian Equal Opportunity and Human Rights Commission (VEOHRC). ${ }^{38}$

Victorian public authorities are also under a duty under s 38(1) of the Charter of Human Rights and Responsibilities Act 2006 (Vic), which makes it " unlawful for a public authority to act in a way that is incompatible with a human right or, in making a decision, to fail to give proper consideration to a relevant human right". The human rights protected by the Charter include the 
right to: enjoyment of human rights without discrimination, ${ }^{39}$ equal protection of the law without discrimination, and equal and effective protection against discrimination. ${ }^{40}$ 'Discrimination' is defined as that within the scope of the Equal Opportunity Act 2010 (Vic). ${ }^{41}$ The Charter duty cannot be pursued independently as a cause of action, and a breach of the Charter does not sound in damages. ${ }^{42}$ However, under s 39(1) of the Charter, it appears that there is standing to make a complaint for breach of the Charter, if it is linked with another complaint for the same relief via a non-Charter cause of action.

When originally drafted, the lack of individual enforcement in the Charter was seen as an asset. According to Williams, the Charter was more about changing the culture of government than about enforcement and litigation (Williams 2006, p. 899). The Charter was designed to be preventative, and to make human rights a mandatory part of decision making - that is, to mainstream human rights (Williams 2006, p. 893). Thus, it was focused on achieving dialogue about human rights (Williams 2006, pp. 901-2), and requiring decision makers to think and act in a way that respected rights (Schleiger 2011, p. 30). The Charter duty would require public authorities to justify their decision making, rather than to overturn their decisions, even if it was not what a judge would have decided in the circumstances (Schleiger 2011, p. 31). Thus, the Charter provided an incentive for public authorities to think and act transparently, in way that respected human rights (Schleiger 2011, p. 31). Through increased transparency, it was hoped there would be more public satisfaction with the work of government (Schleiger 2011, p. 31). While transparency was a key aim in developing the Charter, there was no subsequent requirement to be proactively transparent or report specific data: accessibility and transparency are only achieved by challenging government actions in superior courts (Brett Young 2015, p.
11). In practice, the VEOHRC has found this to be "inaccessible and inadequate" (VEOHRC 2015, p. 1).

A new era of using transparency to achieve equality might be emerging in Victoria. In February 2020, the Victorian Parliament passed the Gender Equality Act 2020 (Vic) (GE Act), which seeks to promote gender equality across the Victorian public service. The GE Act creates a number of new duties and processes that are designed to promote gender equality across public sector organisations, universities and local councils with more than 50 employees ("defined entities" ${ }^{43}$ ), and commenced on 31 March 2021.

More specifically, the GE Act imposes a new duty to promote gender equality on these organisations, requiring them to: (a) consider and promote gender equality; and (b) take necessary and proportionate action towards achieving gender equality in developing policies and programs and delivering public services (s 7). This duty does not give rise to individual enforcement rights, or create grounds for review or affect the validity of any act (s 8).

Further, the GE Act requires defined entities to:

- undertake workplace gender audits, to assess gender equality and inequality in the entity's workplace (s 11).

- develop and implement Gender Equality Action Plans, drawing on the results of a workplace audit, and including strategies for achieving workplace gender equality (s 10).

- undertake gender impact assessments when developing or reviewing any policy, or public program or service, to ensure they take into the account the needs of people of all genders (s 9).

- make "reasonable and material progress" towards workplace gender equality indicators (s 16(1)), including

\footnotetext{
${ }^{39}$ Charter of Human Rights and Responsibilities Act 2006 (Vic) s 8(2).

${ }^{40}$ Ibid s 8(3).

${ }^{41}$ Ibid s 3(1).

${ }^{42}$ Ibid s 39(3).

${ }^{43}$ Gender Equality Act 2020 (Vic) s 5(1).
} 
- gender composition of all levels of the workforce;

- gender composition of governing bodies;

- equal remuneration for work of equal or comparable value;

- sexual harassment;

- recruitment and promotion practices;

- availability and utilisation of terms, conditions and practices relating to family violence leave, flexible working arrangements, and working arrangements supporting employees with family or caring responsibilities;

- gendered segregation within the workplace; and

○ any other prescribed matters (s 3).

- publicly report on progress every two years (s 19), including on gender impact assessments undertaken, progress towards the Gender Equality Action Plan, and progress to meeting the workplace gender equality indicators and any targets or quotas ( $\mathrm{s}$ 19(3)).

The Minister may also issue guidelines in relation to the allocation of funding (s 48) and procurement (s 49).

The GE Act explicitly seeks to make progress towards gender equality transparent, through the publication of Gender Equality Action Plans and progress reports (s 20). Further, it requires organisations to gather, analyse, report on and integrate data into their decisionmaking, including data on intersectional inequality (ss $9(2)(c), 11(2)(c))$. The GE Act explicitly requires defined entities to base their gender workplace audit on genderdisaggregated data and, if available, data about Aboriginality, age, disability, ethnicity, gender identity, race, religion and sexual orientation (s 11(3)). Thus, the Act may encourage defined entities to adopt a more datadriven and intersectional approach to workforce management.

The GE Act also includes consultation as an essential feature of its procedural requirements, explicitly requiring defined entities to consult when preparing Gender
Equality Action Plans (s 10(2)(b)) and to publish Gender Equality Action Plans on their website and notify relevant stakeholders of the publication (s 12(3)). On paper, then, the GE Act appears to make basic provision for an 'action cycle' in relation to gender equality, involving stakeholders in analysing, critiquing, and feeding back information (Landau and Marshall 2018, 329). It remains to be seen how entities embrace these provisions, and the effectiveness of these provisions in practice.

Importantly, then, the GE Act also provides for the centralised monitoring and aggregation of reports and plans, and enforcement of obligations, via the newly formed Public Sector Gender Equality Commissioner (s 28). The Commissioner is required to keep a register of Gender Equality Action Plans (s 14(1)), a register of progress reports (s 21), and may publish Gender Equality Action Plans (s 14(2)). The Commissioner may issue compliance notices for a failure to publish a Gender Equality Action Plan or progress report, or a failure to make progress (s 22). If compliance notices are not complied with, the Commissioner may accept written enforceable undertakings (s 27), recommend ministerial action, publicly name the entity, or apply for a Tribunal order directing compliance (s 26). As noted above, the centralised collection and analysis of data is particularly important in promoting transparency. Further, having a dedicated body for monitoring, enforcing and promoting compliance is likely to be essential for the effective adoption of this legislation.

\subsubsection{TASMANIA}

A positive duty is also imposed on Tasmanian organisations by s 104 of the Anti-Discrimination Act 1998 (Tas). Under that duty, an organisation must "take reasonable steps to ensure that no member, officer, employee or agent of the organisation engages in discrimination or prohibited conduct" ${ }^{44}$ Further, organisations must ensure that their members, officers, employees and agents are aware of conduct prohibited by the Act, notified of any Tribunal order resulting from an inquiry,

\footnotetext{
${ }^{44}$ Anti-Discrimination Act 1998 (Tas) s 104(2).
} 
and do not engage in, repeat or continue such conduct. ${ }^{45}$ Failure to comply with this duty means an organisation is liable for any contravention of the Act which is committed by its members, officers, employees and agents. ${ }^{46}$ Again, this duty is less focused on transparency or the publication of information.

\subsubsection{AUSTRALIAN CAPITAL TERRITORY}

A duty is also in operation in the Australian Capital Territory under the Human Rights Act 2004 (ACT). Under s 40B(1), it is unlawful for a public authority: (a) to act in a way that is incompatible with a human right; or (b) in making a decision, to fail to give proper consideration to a relevant human right.

Human rights include, under s 8(3) of the Act, "the right to equal and effective protection against discrimination on any ground". Unlike in Victoria, individual enforcement is possible in the ACT: s 40C enables individuals to start Supreme Court proceedings against a public authority if they would be a "victim" of the contravention of the duty. The Supreme Court may grant any appropriate relief except damages. ${ }^{47}$ While the ACT duty seeks to mainstream equality, there is no broader obligation to publish information to promote transparency.

\subsection{GENDER PAY GAP REPORTING}

In addition to general obligations under positive duties, more specific obligations are imposed in the UK and Australia in relation to gender pay gap reporting.

\subsubsection{UNITED KINGDOM}

The Equality Act 2010 (UK) includes two provisions relevant to pay transparency. First, s 77 protects "relevant pay disclosures" - that is, disclosures "made for the purpose of enabling the person who makes it, or the person to whom it is made, to find out whether or to what extent there is, in relation to the work in question, a connection between pay and having (or not having) a particular protected characteristic". ${ }^{48}$ A term of work which seeks to prevent a relevant pay disclosure is unenforceable. ${ }^{49}$

Section 78 of the Equality Act 2010 (UK) makes provision for regulations requiring publication of gender pay gap information, for employers with at least 250 employees. While this was originally due to commence in 2013, the Coalition Government decided in 2010 not to implement the provision as planned (Deakin, McLaughlin, and Chai 2011, p. 118). Annual gender pay gap reporting was (finally) introduced for UK employers by the Equality Act 2010 (Specific Duties and Public Authorities) Regulations 2017 (UK) SI 353/2017 and Equality Act 2010 (Gender Pay Gap Information) Regulations 2017 (UK) SI 172/2017. Unlike the PSED, this applies to both the public and private sectors (for employers with over 250 employees), and will likely cover around 50 per cent of UK employees (GOV.UK 2017c). Reports need to include mean and median gender pay gap figures for hourly pay, the proportion of men and women in each pay quartile, and mean and median gender pay gaps for any bonuses paid, as well as the proportion of men and women receiving bonuses (GOV.UK 2017c; 2017a). Employers are also "encouraged" to publish an action plan detailing steps that will be taken to address the gender pay gap (GOV.UK 2017c), and a supporting narrative that "helps anyone reading the statement to understand your organisation's view of why a gender pay gap is present and what the organisation intends to do to close it" (GOV.UK 2017b). Annual pay gap reports must be uploaded on a company website that is accessible to employees and the public (and left up for three years) and to a government website.

\footnotetext{
${ }^{45}$ Anti-Discrimination Act 1998 (Tas) s 104(1). It is unclear whether this latter requirement only relates to the conduct which is the subject of a Tribunal order.

${ }^{46}$ Anti-Discrimination Act 1998 (Tas) s 104(3). This presumably relaxes the requirement for a claimant to establish vicarious liability and/or agency.

${ }^{47}$ Human Rights Act 2004 (ACT) s 40C(4). The time limit on such claims is a year, unless the Court orders otherwise: s 40C(3).

${ }^{48}$ Equality Act 2010 (UK) s 77(3).

${ }^{49}$ Ibid s 77(1)-(2).
} 
The government website - the Gender Pay Gap Service offers users the ability to search by organisation or sector, and to download a spreadsheet which will be populated with employer data. 50

While there are no specific penalties for failing to comply with the reporting requirements, non-compliance is an unlawful act falling within the EHRC's existing enforcement powers. The EHRC sent enforcement letters to 1,456 companies on 9 April 2018 for failing to file gender pay gap information; enforcement action was also taken against 100 companies which submitted questionable data (Barr and Perraudin 2019). However, one statistician estimated in May 2018 that $10-15 \%$ of the 10,504 organisations that submitted data had entered incorrect information (Marriott 2018). In 2019, the EHRC wrote to 47 organisations who failed to report. It entered into formal agreements with one organisation for a failure to report, and with four organisations for a failure to report on time; and started an investigation into the adequacy of one organisation's data. Following this enforcement action, all employers complied with reporting requirements (Equality and Human Rights Commission 2021).

Even with these errors and gaps in reporting, it appears gender pay gap reporting is having a significant impact in practice. Blundell (2021), for example, argues that women's strong preference against high pay gap employers has forced some organisations to close their pay gap by as much as $1.6 \%$. Duchini, Simion and Turrell (2020) argue that pay transparency has increased the probability that women are hired in above-medianwage occupations by $5 \%$.

\subsubsection{AUSTRALIA}

In Australia, reporting obligations in relation to gender equality are imposed by the Workplace Gender Equality Act 2012 (Cth) (WGE Act), which applies to non-public sector employers ${ }^{51}$ and higher education providers with 100 or more employees. Employers are required to report on topics including equal pay, gender composition of the workforce, gender composition of governing bodies, flexible work arrangements, consultation in relation to gender equality, and sex-based harassment and discrimination (including relevant policies and training that are in place) against minimum standards. ${ }^{52}$ The reports are public and must be signed by the organisation's Chief Executive Officer. ${ }^{53}$ Employers who fail to lodge a report or provide misleading information in a report will be deemed to be non-compliant and may be named by the Workplace Gender Equality Agency (WGEA). ${ }^{54}$ Ultimately such an employer may be prevented from contracting with the Commonwealth government. In her second reading speech, the Minister for the Status of Women, Julie Collins, said that through these measures, the Bill will "allow for more transparency in reporting" and that it "improves the transparency and fairness of the compliance framework and consequences for noncompliance". 55

The WGE Act signified a shift in thinking about gender equality - earlier legislation required only procedural compliance (namely reporting) without any benchmarking against standards or penalties for noncompliance other than being named in a report. Many employers failed to report at all. Under the new WGE Act, businesses have more certainty about when and what

\footnotetext{
${ }^{50}$ Available at https://gender-pay-gap.service.gov.uk/.

${ }^{51}$ The Australian Public Service Commission is required to collect data about the composition of the Commonwealth public service: Public Service Act 1999 (Cth), s 44. This is published in its annual State of the Service report: see https://www.apsc.gov.au/initiativesand-programs/workforce-information/research-analysis-and-publications/state-service (accessed 8/4/19). Commonwealth government agencies are also required to take measures to increase female workforce participation: see Equal Employment Opportunity (Commonwealth Authorities) Act 1987 (Cth).

${ }^{52}$ Workplace Gender Equality Act 2012 (Cth) ss 3, 13. See further Workplace Gender Equality (Matters in Relation to Gender Equality Indicators) Instrument 2013 (No 1) (Cth).

${ }^{53}$ Workplace Gender Equality Act 2012 (Cth) s 13

${ }^{54}$ Ibid ss 13A, 16, 19B, 19C, 19D.

${ }^{55}$ Commonwealth, Parliamentary Debates, House of Representatives, 1March 2012, 2440 (Julie Collins).
} 
they need to report on, and are able to measure their progress over time. According to the Minister, the data gathered by the WGEA would mean it "will know exactly what is happening, and where, in Australian workplaces regarding gender equality practices and outcomes". ${ }^{56}$

The WGEA's dataset, which consolidates the information reported by employers, captures data relating to around $40 \%$ of Australian employees (Workplace Gender Equality Agency 2017a, 5). This data is made accessible and available in three key ways. First, individual organisational reports are available online at the WGEA's website (Workplace Gender Equality Agency 2017b): between January 2014 and 2016, these public reports were downloaded over 30,000 times (Workplace Gender Equality Agency 2017a, 8). Second, the WGEA offers compliant reporting organisations access to a confidential and customised Competitor Analysis Benchmark Report, which highlights organisational performance relative to others. This is thought to help organisations identify and set realistic goals for improvement and track their progress over time. In 201516 , of organisations that were offered a report, $37.1 \%$ accessed the material. ${ }^{57}$ However, these benchmark reports are only offered to organisations themselves, and not to employees, unions, and the general public. This may impede the potential to create a market for equal employment opportunities in Australia (Smith and Hayes 2015, p. 195). Third, the WGEA has created a Data Explorer, which allows the public to access aggregated reported information, and analyse trends by industry (Workplace Gender Equality Agency n.d.). The Data Explorer had 20,053 unique users between 1 July 2018 and 30 June 2019 (Workplace Gender Equality Agency 2019, pp. 20-21).

Overall, the WGEA model reflects a comprehensive approach to consolidating organisational reporting, and making information accessible and useable. However, the WGEA reporting process is limited in scope, as it only covers large private sector employers and higher education providers, and only relates to sex (and not other protected attributes). The WGEA has recommended that consideration be given to at least allowing for voluntary reporting by excluded employers (that is, those in the public sector or with less than 100 employees), to enhance the national dataset and "create a much fuller and accurate picture of gender equality" (Workplace Gender Equality Agency 2017a, p. 23). Further, the AHRC's 2016 Willing to Work report recommended that the mandate of the WGEA be expanded, to become the Workplace Gender Equality and Diversity Agency, to allow monitoring and reporting across all attributes (AHRC 2016, p. 14).

The WGEA model appears to have been successful at securing organisational reporting: comparatively few organisations have failed to comply with their reporting obligations, as represented in Table 1 (Workplace Gender Equality Agency 2017a, p. 24). The slight increase in non-compliance in 2015-16 represents a shift in the WGEA's approach to non-reporting: in the first two years, the WGEA engaged repeatedly with late and nonreporters to secure compliance (Workplace Gender Equality Agency 2017a, p. 24). These efforts have been reduced since the 2015-16 reporting year, resulting in a larger number of non-compliant organisations. These numbers are no longer specifically reported in WGEA's 2018-19 annual report; however, as at 24 July 2020, WGEA included 124 organisations on its non-compliant list out of 4,841 reporting organisations in 2018-19 (2.56\% ) (Workplace Gender Equality Agency 2020).

TABLE 1: Non-compliant organisations (Source: WGEA)

\begin{tabular}{|l|l|l|l|}
\hline $\begin{array}{l}\text { Reporting pe- } \\
\text { riod }\end{array}$ & $\begin{array}{l}\text { Non-compliant } \\
\text { organisations }\end{array}$ & $\begin{array}{l}\text { Reporting or- } \\
\text { ganisations }\end{array}$ & $\begin{array}{l}\text { \% non-compli- } \\
\text { ant }\end{array}$ \\
\hline $2013-14$ & 44 & 4456 & 0.99 \\
\hline $2014-15$ & 44 & 4686 & 0.94 \\
\hline $2015-16$ & 74 & 4707 & 1.57 \\
\hline
\end{tabular}

\section{DISCUSSION AND CONCLUSION}

Organisational transparency offers dramatic potential to recast the way in which we address inequality. Particularly in relation to gender equality, with the passing

\footnotetext{
${ }^{56}$ Commonwealth, Parliamentary Debates, House of Representatives, 1 March 2012, 2440 (Julie Collins).

57 Workplace Gender Equality Agency. 2016. 'Annual Report 2015-16', 20. This statistic was not reported in $2018-19$.
} 
of the GE Act in Victoria and the establishment of the WGEA at the federal level, there is renewed potential for an active cycle of transparency, reporting, engagement, and action. These two jurisdictions also offer an important model for how information might be centrally aggregated, analysed and fed back to organisations. The issue, of course, is that the Victorian measures only apply to the public sector, and the WGEA only covers large private sector employers and universities. In the UK, positive duties only apply to public entities, though gender pay gap reporting has been extended to all large organisations in the public and private sectors.

Extending transparency measures and reporting to all employers does not make logical sense: for small employers, with only a handful of employees, data analysis is at best unhelpful and unnecessary. However, covering both the public and the private sector is a logical expansion of existing regimes. Further, extending coverage to employers with at least 100 employees (as is the case at the federal level in Australia) or even 50 employees (as in Victoria) would be a sensible step, particularly given widespread employment by medium-sized enterprises in both Australia and the UK.

The existing limited scope of positive duties-applying exclusively to the public sector in the UK-reflects the public/private dichotomy in equality law. As Thornton (1991) has argued, equality is only accessible in the public sphere; however, as public services are increasingly privatised, and the public/private divide becomes more permeable, this is problematic.

While transparency has significant potential in this area, we must pay concerted attention to how these measures are implemented and adopted. In other areas of law and policy, increased transparency has not always achieved its aims in practice. For example, in the context of modern slavery, Landau and Marshall (2018) argue that supply chain transparency is increasing the awareness of various stakeholders of issues of modern slavery, and prompting the adoption of organisational policies and processes. However, transparency legislation in that context does not make any particular action or inaction illegal, and the legislation is limited in scope to just cover the largest businesses (Landau and
Marshall 2018, p. 326). Further, the quality of reporting can be variable (Landau and Marshall 2018, p. 327), and the regulatory regime risks prompting "superficial or cosmetic forms of compliance"-a tick box mentality (Landau and Marshall 2018, p. 328). Thus, Landau and Marshall (2018, p. 325) argue that transparency is just "one among many tools that can be used to promote greater corporate accountability for labour exploitation in domestic and transnational supply chains". The question, then, is whether transparency is enough to prompt meaningful change; and what if, for example, people are willing to tolerate inequality, and transparency does not prompt action?

Transparency can also be fragile: in the UK, for example, gender pay gap reporting was suspended in 2019-20 due to the COVID-19 pandemic; a further 6month extension on enforcement action was granted in 2021 (Government Equalities Office 2021). This may mean organisations have even less incentive to consider the gendered impact of COVID-19 on their workforce. As the UK House of Commons Women and Equalities Committee (2021, p. 37) argued, in seeking the urgent reinstatement of gender pay gap reporting: "this should have been a time for more-not less-transparency".

Recognising these challenges, this paper has put forward five key criteria for ensuring the efficacy of transparency effected via positive equality duties. There must be a focus on (1) information quality and (2) accessibility, including via central aggregation and benchmarking; (3) consultation and engagement with information users; (4) effective procedures to monitor, scrutinise and enforce positive duties and (5) a focus on making policies sustainable, so they grow in use and scope over time. As we seek to advance transparency to encompass all protected characteristics-beyond existing provisions on gender equality and gender pay gap reporting-these are important principles to keep in mind.

It is clear, too, that transparency should not supplant other forms of regulation, but can be a useful complement to them (Fung, Graham, and Weil 2007, pp. 37, 176). Further, there is a need for rigorous research to monitor and evaluate transparency measures as they 
are implemented in practice. A particular challenge for equality law is achieving meaningful engagement of stakeholders with organisational reporting. While there are engagement mechanisms in place for some jurisdictions, it is unclear the extent to which this 'action cycle' is being achieved in practice. Overall, then, the substantial potential of transparency to advance equality may not yet be achieved in practice. Future regulatory reform must remain attuned to the need to promote the active cycle of engagement between organisations and stakeholders, and the need to promote accessible, meaningful, and detailed information disclosures.

\section{REFERENCES}

1. Australian Human Rights Conmission. 2016. "Willing to Work: National Inquiry into Employment Discrimination Against Older Australians and Australians with Disability". Sydney.

2. Allen, D., Blackham, A. 2019. "Under Wraps: Secrecy, Confidentiality and the Enforcement of Equality Law in Australia and the UK". Melbourne University Law Review 43 (2): 384-422.

3. Barnes, H., Smeaton, D., Taylor, T. 2009. "An Ageing Workforce: The Employer's Perspective”. 468. Brighton. https://westminsterresearch.westminster.ac.uk/item/90vwx/an-ageing-workforcethe-employer-s-perspective

4. Barnes, J., Burke, T. F. 2012. "Making Way: Legal Mobilization, Organizational Response, and Wheelchair Access". Law \& Society Review 46: 167-98.

5. Barr, C., Perraudin, F. 2019. "Lack of Sanctions 'Makes a Mockery' of Gender Pay Gap Reports". The Guardian, 28 February 2019, sec. Society. http://www.theguardian.com/society/2019/feb/28/lack-of-sanctions-makes-amockery-of-gender-pay-gap-reports

6. Blackburn, R., Hart, M. 2003. "Employment Rights in Small Firms: Some New Evidence, Explanations and Implications". Industrial Law Journal 32 (1) 60-67. https://doi.org/10.1093/ilj/32.1.60.

7. Blackham, A. 2019. "Re-Systematising Labour Law: Beyond Traditional Systems Theory and Reflexive Law?" In Theorising Labour Law in a
Changing World: Towards Inclusive Labour Law, edited by Alysia Blackham, Miriam Kullmann, and Ania Zbyszewska, 189-206. Oxford: Hart.

8. ——- 2020. "Why Do Employment Age Discrimination Cases Fail? An Analysis of Australian Case Law". Sydney Law Review 42 (1): 1-35.

9. Blackham, A., Allen, D. 2019. "Resolving Discrimination Claims Outside the Courts: Alternative Dispute Resolution in Australia and the United Kingdom". Australian Journal of Labour Law 31: 25378.

10. Blackham, A., Temple, J. 2020. "Intersectional Discrimination in Australia: An Empirical Critique of the Legal Framework". UNSW Law Journal 43 (3): 773-800.

11. Blundell, J. 2021. "Wage Responses to Gender Pay Gap Reporting Requirements". CEPDP1750. https://cep.lse.ac.uk/ new/publications/abstract.asp?index $=7804$

12. Breitenbach, E. 2004. "The Scottish Executive and Equality”. Etudes Ecossaises, no. 9. http://www.docs.hss.ed.ac.uk/education/creid/projects/07xiii esrc seminar2 papereb.pdf

13. Brett Young, M. 2015. "From Commitment to Culture: The 2015 Review of the Charter of Human Rights and Responsibilities Act 2006 - Summary Report". Melbourne.

14. Company Reporting: Gender Pay Data. London. Accessed 17 July 2020.

https://assets.publishing.service.gov.uk/government/uploads/system/uploads/attachment data/file/445458/Company Reporting GPG research.pdf

15. Davies, A. C. L. 2009. Perspectives on Labour Law. 2nd ed. Law in Context. Cambridge University Press.

16. Deakin, S., McLaughlin, C., Chai, D.H. 2011. “Gender Inequality and Reflexive Law: The Potential of Different Regulatory Mechanisms for Making Employment Rights Effective". Working Paper 426. Cambridge.

https://www.cbr.cam.ac.uk/wp-content/uploads/2020/08/wp426.pdf 
17. Deakin, S., McLaughlin, C., Chai, D. 2012. “Gender Inequality and Reflexive Law: The Potential for Different Regulatory Mechanisms". In Making Employment Rights Effective: Issues of Enforcement and Compliance, edited by Linda Dickens, 115-38. Oxford: Hart.

18. Dickens, L. 2006. "Equality and Work-Life Balance: What's Happening at the Workplace". Industrial Law Journal 35 (4): 445-49.

https://doi.org/10.1093/indlaw/dwl035

19. _- _ 2007. "The Road Is Long: Thirty Years of Equality Legislation in Britain". British Journal of Industrial Relations 45 (3): 463-94.

https://doi.org/10.1111/j.1467-

8543.2007.00624.X

20. Duchini, E., Simion, S., Turrell, A. 2020. "Pay Transparency and Cracks in the Glass Ceiling". CAGE Online Working Paper Series 482.

21. EHRC. 2012. "Publishing Equality Information: Commitment, Engagement and Transparency". London.

22. ———. 2017. "Measuring Up? Report 7: Public Authorities' Performance in Meeting the Scottish Specific Equality Duties, 2017".

23. Equality and Human Rights Commission. 2021. "Gender Pay Gap: Our Enforcement Action". Equality and Human Rights Commission. 25 February 2021.

https://www.equalityhumanrights.com/en/paygaps/gender-pay-gap-our-enforcement-action

24. Equality and Human Rights Commission Scotland. 2015a. "Measuring Up? Report 4: Performance". Edinburgh.

http://www.equalityhumanrights.com/sites/default/files/publication pdf/measuring up 4 performance final 1.pdf

25. ———. 2015b. "Measuring Up? Report 4: Practice". Edinburgh. http://www.equalityhumanrights.com/sites/default/files/publication pdf/measuring up 4 practice final 2.pdf

26. Felstead, A., Jewson, N., Phizacklea, A., Walters, S. 2002. "Opportunities to Work at Home in the Context of Work-Life Balance". Human Resource Management Journal 12 (1): 54-76.
27. Foster, D. 2015. "Devolution and Disabled Workers: The Experiences of Union Equality Representatives in Wales: Devolution, Disabled Workers and Equality Representatives". Industrial Relations Journal 46 (2): 153-68. https://doi.org/10.1111/irj.12096

28. Fredman, S. 2008. Human Rights Transformed: Positive Rights and Positive Duties. Oxford: Oxford University Press.

29. - - - 2011. Discrimination Law. 2nd ed. Clarendon Law Series. Oxford: Oxford University Press.

30. —— - 2012. "Breaking the Mold: Equality as a Proactive Duty". American Journal of Comparative Law 60: 265-88.

31. Fung, A., Graham, M., Weil, D. 2007. Full Disclosure: The Perils and Promise of Transparency. New York: Cambridge University Press.

32. Government Equalities Office. 2010. "Equality Act 2010: The Public Sector Equality Duty. Promoting Equality through Transparency: A Consultation". London.

33. - - 2015. "Closing the Gender Pay Gap: Government Consultation". London.

https://assets.publishing.service.gov.uk/government/uploads/system/uploads/attachment data/file/450878/Gender Pay Gap Consultation.pdf

34. ———. 2021. "Gender Pay Gap Reporting: Changes to Enforcement". GOV.UK. 23 February 2021.

https://www.gov.uk/guidance/gender-pay-gapreporting-changes-to-enforcement

35. GOV.UK. 2017a. "Gender Pay Gap Reporting: Overview". GOV.UK. 6 March 2017. https://www.gov.uk/guidance/gender-pay-gapreporting-overview

36. _- - 2017b. "Gender Pay Gap Reporting: What Employers Must Publish”. GOV.UK. 6 March 2017. https://www.gov.uk/guidance/gender-pay-gapreporting-what-employers-must-publish

37. ———. 2017c. "Gender Pay Gap Reporting Goes Live”. GOV.UK. 12 April 2017.

https://www.gov.uk/government/news/gender-pay-gap-reporting-goes-live 
38. Grosser, K., Moon, J. 2008. “Developments in Company Reporting on Workplace Gender Equality?" Accounting Forum 32 (3): 179-98. https://doi.org/10.1016/j.accfor.2008.01.004

39. Hepple, B. 2011. "Enforcing Equality Law: Two Steps Forward and Two Steps Backwards for Reflexive Regulation". Industrial Law Journal 40 (4): 315-35.

https://doi.org/10.1093/indlaw/dwr020

40. Hoque, K., Noon, M. 2004. "Equal Opportunities Policy and Practice in Britain: Evaluating the "Empty Shell" Hypothesis". Work, Employment \& Society 18 (3): 481-506. https://doi.org/10.1177/0950017004045547

41. James, E. H., Wooten, L.P. 2006. "Diversity Crises: How Firms Manage Discrimination Lawsuits". Academy of Management Journal 49 (6): 1103-18. https://doi.org/10.5465/AMJ.2006.23478091

42. Kersley, B., Alpin, C., Forth, J., Bryson, A., Bewley, H., Dix, G., Oxenbridge, S. 2006. Inside the Workplace: Findings from the 2004 Workplace Employment Relations Survey. Abingdon: Routledge.

43. Landau, I., Marshall, S. 2018. "Should Australia Be Embracing the Modern Slavery Model of Regulation?" Federal Law Review 46 (2): 313-39.

https://doi.org/10.1177/0067

205X1804600206

44. Manfredi, S., Vickers, L., Clayton-Hathway, K. 2018. "The Public Sector Equality Duty: Enforcing Equality Rights Through Second-Generation Regulation". Industrial Law Journal 47 (3): 365-98. https://doi.org/10.1093/indlaw/dwx022

45. McCrudden, C. 1998-1999. "Mainstreaming Equality in the Governance of Northern Ireland". Fordham International Law Journal 22: 1696.

46. Nigel, M. 2018. "1 in 10 Organisations Have Published Incorrect Gender Pay Gap Data. Are You One of Them?" Nigel Marriott's Blog (blog). 12 May 2018. https://marriott-stats.com/nigelsblog/1-in-10-orgs-published-incorrect-genderpay-gap-data/.

47. Owen, D. L. 2003. "Recent Developments in European Social and Environmental Reporting and $\mathrm{Au}-$ diting Practice-A Critical Evaluation and Tenta- tive Prognosis". Research paper, no. 3. International Centre for Corporate Social Responsibility, Nottingham University.

https://citeseerx.ist.psu.edu/viewdoc/download?doi=10.1.1.203.5484\&rep=rep1\&type=pdf

48. Schleiger, M. 2011. "One Size Fits All: The Obligation of Public Authorities to Consider Human Rights under the Victorian Charter". Australian Journal of Administrative Law 19 (1): 17-32.

49. Scottish Government. 2015. Equality Outcomes and Mainstreaming Report 2015. Edinburgh: Scottish Government. http://www.gov.scot/Publications $/ 2015 / 04 / 7781 / 0$

50. Smith, B., Hayes, M. 2015. "Using Data to Drive Gender Equality in Employment: More Power to the People?" Australian Journal of Labour Law 28: 191.

51. Sturm, S. 2001. "Second Generation Employment Discrimination: A Structural Approach". Columbia Law Review 101 (3): 458. https://doi.org/10.2307/1123737

52. Thornton, M. 1991. "The Public/Private Dichotomy: Gendered and Discriminatory". Journal of Law and Society 18 (4): 448-63.

https://doi.org/10.2307/1410319

53. VEOHRC. 2015. "Eight-Year Charter Review - Position Paper: Legal Proceedings and Remedies". Melbourne.

54. Williams, G. 2006. "The Victorian Charter of Human Rights and Responsibilities: Origins and Scope". Melbourne University Law Review 30 (3): 880-905.

55. Women and Equalities Committee. 2018a. "Older People and Employment". Fourth Report of Session 2017-19, HC 359. London.

56. —— - 2018b. "Older People and Employment: Government and Equality and Human Rights Commission Responses to the Committee's Fourth Report of Session 2017-19". Sixth Special Report of Session 2017-19, HC 1585. London. https://publications.parliament.uk/pa/cm201719/cmselect/cmwomeq/15 85/1585.pdf 
57. ——_. 2021. "Unequal Impact? Coronavirus and the Gendered Economic Impact”. HC 385 Fifth Report of Session 2019-21. https://committees.parliament.uk/publications/4597/documents/46478/default/

58. Wood, S. J., de Menezes, L.M., Lasaosa, A. 2003. "Family-Friendly Management in Great Britain: Testing Various Perspectives". Industrial Relations 42 (2): 221-50. https://doi.org/10.1111/1468-232X.00288

59. Wooten, L.P., James, E.H. 2004. "When Firms Fail to Learn: The Perpetuation of Discrimination in the Workplace". Journal of Management Inquiry 13 (1): 23-33. https://doi.org/10.1177/1056492603259059

60. Workplace Gender Equality Agency. 2016. “Annual Report 2015-16". Sydney.
61. - - - 2017a. Progress Report 2014-16. Sydney: Workplace Gender Equality Agency.

62. __—. 2017b. "Public Reports". Workplace Gender Equality Agency. 2017. https://www.wgea.gov.au/report/public-reports

63. ———. 2019. "Annual Report 2018-19”. Sydney. https://www.wgea.gov.au/sites/default/files/documents/wgea-annual-report-1819.pdf

64. —_- 2020. "Non-Compliant List". Workplace Gender Equality Agency. 24 July 2020. https://www.wgea.gov.au/non-compliant-list

65. —— - n.d. "WGEA Data Explorer". WGEA Data Explorer. Accessed 12 July 2017. http://data.wgea.gov.au/ 